\title{
Supply chain integration scales validation and benchmark values
}

\author{
Juan A. Marin-Garcia, ${ }^{1}$ Rafaela Alfalla-Luque, ${ }^{2}$ Carmen Medina-López ${ }^{2}$ \\ ${ }^{1}$ ROGLE - Dept. Organización de Empresas. Universidad Politécnica de Valencia (Spain) \\ ${ }^{2}$ Dpto. Economia Financiera y Dirección de Operaciones. F.CC. Económicas \\ y Empresariales de Sevilla. Universidad de Sevilla. (Spain) \\ jamarin@omp.upv.es, alfalla@us.es, cmedina@us.es
}

Received: August 2012

Accepted: May 2013

\section{Abstract:}

Purpose The clarification of the constructs of the supply chain integration (clients, suppliers, external and internal), the creation of a measurement instrument based on a list of items taken from earlier papers, the validation of these scales and a preliminary benchmark to interpret the scales by percentiles based on a set of control variables (size of the plant, country, sector and degree of vertical integration).

Design/methoddogy/approadr Our empirical analysis is based on the HPM project database (20052007 timeframe). The international sample is made up of 266 plants across ten countries: Austria, Canada, Finland, Germany, Italy, Japan, Korea, Spain, Sweden and the USA. In each country. We analized the descriptive statistics, internal consistency testing to purify the items (inter-item correlations, Cronbach's alpha, squared multiple correlation, corrected item-total correlation), exploratory factor analysis, and finally, a confirmatory factor analysis to check the convergent and discriminant validity of the scales. The analyses will be done with the SPSS and EQS programme using the maximum likelihood parameter estimation method.

Findings: The four proposed scales show excellent psychometric properties.

Researdh limitations/implications: with a clearer and more concise designation of the supply chain integration measurement scales more reliable and accurate data could be taken to analyse the relations between these constructs with other variables of interest to the academic 1 fields. 
Practical implications: providing scales that are valid as a diagnostic tool for best practices, as well as providing a benchmark with which to compare the score for each individual plant against a collection of industrial companies from the machinery, electronics and transportation sectors.

Originality/value supply chain integration may be a major factor in explaining the performance of companies. The results are nevertheless inconclusive, the vast range of results obtained are due, amongst other things, to the fact that there is no exactness to the group of scales used, noone has yet published an analysis of the measurement models nor clear benchmarks as to the variety of the scales used.

Keywords: scale validation, questionnaire, reliability, validity, psichometric properties, supply chain integration

\section{Introduction}

The concept of supply chain integration is of great interest for academics working in operational management (Zhao, Huo, Selen \& Yeung, 2011; Flynn, Huo \& Zhao, 2010). One of the main reasons is that it greatly influences the competitive advantage of companies (Flynn et al., 2010; Chang, Ik-Whan \& Dennis, 2007; Alfalla-Luque, Medina-Lopez \& Schrage, 2012). But it is also a concept whose definition and whose operationalization are still up for debate. There is no consensus as to which components to include, nor how to measure them (Roth, Schroeder, Huang \& Kristal, 2008; Zhu, Sarkis \& Lai, 2008; Li, Rao, Ragu-Nathan \& RaguNathan, 2005; Flynn et al., 2010, Alfalla-Luque, Medina-Lopez \& Dey, 2012). In fact, in research carried out so far, it is common to be confronted with a variety of proposals and this means that demonstrating the effects of supply chain integration on the performance of companies is inconclusive giving contradictory results (Zhao et al., 2011; Chang et al., 2007; Flynn et al., 2010).

According to recent research, supply chain integration is comprised of two primary dimensions: internal integration and external integration. External integration can then be further subdivided: integration with clients and integration with suppliers (Chang et al., 2007; Flynn et al., 2010; Flynn, Wu \& Melnyk, 2010; Narasimhan \& Kim, 2002; Topolsek, 2011; Zhao et al., 2011; Alfalla-Luque \& Medina-López, 2009; Carter, Sanders \& Dong, 2008; Kaynak \& Hartley, 2008; Li, Ragu-Nathan, Ragu-Nathan \& Subba Rao, 2006). Nevertheless, there is a slight bias in research, both empirical and conceptual, that has leant towards external rather than internal integration (Zhao et al., 2011). This is why there have been calls so that any future research takes into account the relationships between the different components of the supply chain integration and the effect that each one has on the performance indicators of the company (Chang et al., 2007; Flynn et al., 2010; Narasimhan \& Kim, 2002; Zhao et al., 2011). 
To help with the development of the proposed future research, in this paper our objectives are the clarification of the constructs, the creation of a measurement scale for the components of the supply chain integration, the validation of these scales and a preliminary study on the effects of a variety of control variables (size of the plant, country, sector and degree of vertical integration) in the values of these scales.

\section{Definitions of integration}

According to Flynn et al. (2010) supply chain integration can be defined as:

"the degree to which a manufacturer strategically collaborates with its supply chain partners and collaboratively manages intra- and inter-organization processes. The goal is to achieve effective and efficient flows of products and services, information, money and decisions, to provide maximum value to the customer at low cost and high speed."

This is why it is so important to instil confidence amongst all the agents, building long-term relationships, frequent communication, share both profit and risk, and look for effective ways of sharing information, make joint decisions and resolve conflicts (Flynn et al., 2010). There are two main types of integration: external integration and internal integration (Zhao et al., 2011; Chang et al., 2007; Flynn et al., 2010).

Internal integration refers to the degree to which a company can organise its practices, procedures, information, decisions and conduct in a collaborative and synchronised way between its different areas, to be able to comply with client requirements and effectively interact with its suppliers (Zhao et al., 2011; Topolsek, 2011; Flynn et al., 2010; Flynn et al., 2010).

External integration refers to the degree to which a company understands the need of its clients and collaborates with clients and/or suppliers to develop inter-organisational strategies and shared practices and processes, so that it manages to satisfy its clients' needs (Flynn et al., 2010). External integration consists of integration with clients and integration with suppliers (Flynn et al., 2010; Zhao et al., 2011; Escrig Tena \& Bou-Llusar, 2005).

According to earlier work, there are close ties between the three basic components of integration (internal, clients and suppliers) (Chang et al., 2007; Escrig Tena \& Bou-Llusar, 2005). So it could be construed that internal integration is the precursor to achieving external integration (Flynn et al., 2010; Pagell \& LePine, 2002; Bessant, Kaplinsky \& Morris, 2003; Harrison \& Van Hoek, 2005; Cagliano, Caniato \& Spina, 2006). 


\section{Control variables for supply chain integration}

The use of operational management practices in general, and supply chain integration in particular, are normally affected by national culture, meaning that it is quite common to come across research where the country in which the plant is located explains to a certain extent the degree of use of supply chain integration (Oliver \& Delbridge, 2002; Hofstede, 1998; Zhao et al., 2011; Pagell, Katz \& Sheu, 2005). Another variable that often comes up is the sector (MacDuffie \& Helper, 1997; Bruce, Daly \& Towers, 2004; Bayraktar, Jothishankar, Tatoglu \& Wu, 2007; Oliver \& Delbridge, 2002; Roth et al., 2008; Martinez Jurado \& Moyano Fuentes, 2011). There are also references to the fact that integration is associated with the size of the company (Underhill, 2001; Roth et al., 2008; Zhao et al., 2011). And finally, the degree of vertical integration can affect the type and degree of supply chain integration (Roth et al., 2008; Hayes \& Wheelwright, 1984).

\section{Method}

The aim of this paper is to test the psychometric properties of a questionnaire to identify four constructs of supply chain integration in industrial companies.

We begin looking at a reflective model, where the items of the scales are estimators conditioned by a construct that can not be directly observed. The items therefore reflect this construct and are interchangeable, with the result that any group of these items will provide an estimation equivalent to the phenomenon of interest (Hair, Anderson, Tatham \& Black, 1999; Brown, 2006; Byrne, 2006; Baxter, 2009).

The test bank of items used to build the survey originate from earlier works (Roth et al., 2008). Of these, 4 items have been selected for each construct, aiming to ensure that they are representative of the theoretical definition, used in recent papers, and that they are not redundant, to avoid the survey being excessively long. The score of the scales is the total of the sum of the items (Table 1 ).

Our empirical analysis is based on the HPM project database, the data for which was collected during the third round of this project (2005-2007 timeframe) by an international team of researchers. As a whole, the international sample is made up of 266 plants across ten countries: Austria, Canada, Finland, Germany, Italy, Japan, Korea, Spain, Sweden and the USA. In each country, the plants were randomly selected from three industries: automotive components, electronics and machinery. A stratified sampling design was used to obtain an approximately equal number of plants for each industry-country combination. The items were targeted at plant accounting managers, direct labour, human resource managers, inventory managers, process engineers, plant managers, quality managers, supervisors and plant superintendents. Items are responded to by at least two different managers/workers in the plant. After that, all the responses for each item in each plant were averaged to obtain plant items scores. 


\begin{tabular}{|c|c|c|c|}
\hline Scale & Item & Description & Used in \\
\hline \multirow[t]{4}{*}{$\begin{array}{l}\text { Customer } \\
\text { integration }\end{array}$} & It01 & $\begin{array}{l}\text { We frequently are in close contact } \\
\text { with our customers. }\end{array}$ & $\begin{array}{l}\text { (Kim, 2009; Narasimhan \& Kim, 2002; Sezen, 2008; } \\
\text { Stank, Keller \& Daugherty, 2001; Swink \& Nair, } \\
\text { 2007; Tan, Lyman \& Wisner, 2002; Vickery, } \\
\text { Jayaram, Droge \& Calantone, 2003; Wong \& Boon- } \\
\text { Itt, 2008; Vachon \& Klassen, 2007; Germain \& Iyer, } \\
\text { 2006; Hsu, Kannan, Tan \& Leong, 2008; Flynn et al., } \\
\text { 2010; Thun, 2010) }\end{array}$ \\
\hline & It02 & $\begin{array}{l}\text { Our customers give us feedback on } \\
\text { our quality and delivery } \\
\text { performance. }\end{array}$ & $\begin{array}{l}\text { (Kim, 2009; Narasimhan \& Kim, 2002; Sezen, 2008; } \\
\text { Stank et al., 2001; Swink \& Nair, 2007; Tan et al., } \\
\text { 2002; Vachon \& Klassen, 2007; Hsu et al., 2008; } \\
\text { Flynn et al., 2010; Thun, 2010) }\end{array}$ \\
\hline & It03 & $\begin{array}{l}\text { We strive to be highly responsive to } \\
\text { our customers' needs. }\end{array}$ & $\begin{array}{l}\text { (Kannan \& Tan, 2005; Sezen, 2008; Swink \& Nair, } \\
\text { 2007; Tan et al., 2002; Vachon \& Klassen, 2007; } \\
\text { Hsu et al., 2008; Kulp, Lee \& Ofek, 2004; Thun, } \\
\text { 2010) }\end{array}$ \\
\hline & It04 & $\begin{array}{l}\text { Our customers are actively involved } \\
\text { in our product design process. }\end{array}$ & $\begin{array}{l}\text { (Tan et al., 2002; Vachon \& Klassen, 2007; Hsu et } \\
\text { al., 2008; Kulp et al., 2004) }\end{array}$ \\
\hline \multirow[t]{4}{*}{$\begin{array}{l}\text { External } \\
\text { Integration }\end{array}$} & It05 & $\begin{array}{l}\text { We work as a partner with our } \\
\text { customers. }\end{array}$ & $\begin{array}{l}\text { (Stank et al., 2001; Tan et al., 2002; Wong \& Boon- } \\
\text { Itt, 2008; Hsu et al., 2008; Sanders, 2005; Danese, } \\
\text { Formentini, Romano \& Bortolotti, 2010) }\end{array}$ \\
\hline & It06 & $\begin{array}{l}\text { We work as a partner with our } \\
\text { suppliers, rather than having an } \\
\text { adversarial relationship. }\end{array}$ & $\begin{array}{l}\text { (Kim, 2009; Narasimhan \& Kim, 2002; Wong \& } \\
\text { Boon-Itt, 2008; Hsu et al., 2008; Flynn et al., 2010; } \\
\text { Sanders, 2005) }\end{array}$ \\
\hline & It07 & $\begin{array}{l}\text { We believe that cooperative } \\
\text { relationships will lead to better } \\
\text { performance than adversarial } \\
\text { relationships. }\end{array}$ & $\begin{array}{l}\text { (Swink \& Nair, 2007; Hsu et al., 2008; Bagchi, Ha, } \\
\text { Skjoett-Larsen \& Soerensen, 2005; Giménez \& } \\
\text { Ventura, 2003; Kannan \& Tan, 2005) }\end{array}$ \\
\hline & It08 & $\begin{array}{l}\text { We believe than an organization } \\
\text { should work as a partner with its } \\
\text { surrounding community. }\end{array}$ & $\begin{array}{l}\text { (Sezen, 2008; Hsu et al., 2008; Kannan \& Tan, } \\
\text { 2005) }\end{array}$ \\
\hline \multirow[t]{4}{*}{$\begin{array}{l}\text { Supplier } \\
\text { integration }\end{array}$} & It09 & $\begin{array}{l}\text { We maintain close communication } \\
\text { with suppliers about quality } \\
\text { considerations and design changes. }\end{array}$ & $\begin{array}{l}\text { (Kannan \& Tan, 2005; Kim, 2009; Sanders \& } \\
\text { Premus, 2005; Sezen, 2008; Stank et al., 2001; } \\
\text { Swink \& Nair, 2007; Tan et al., 2002; Wong \& Boon- } \\
\text { Itt, 2008; Vachon \& Klassen, 2007; Hsu et al., } \\
\text { 2008; Flynn et al., 2010) }\end{array}$ \\
\hline & It10 & $\begin{array}{l}\text { We maintain cooperative } \\
\text { relationships with our suppliers. }\end{array}$ & $\begin{array}{l}\text { (Sanders \& Premus, 2005; Stank et al., 2001; Tan et } \\
\text { al., 2002; Vickery et al., 2003; Wong \& Boon-Itt, } \\
\text { 2008; Vachon \& Klassen, 2007; Hsu et al., 2008; } \\
\text { Sanders, 2005; Flynn et al., 2010; Thun, 2010) }\end{array}$ \\
\hline & It11 & $\begin{array}{l}\text { Our customers are actively involved } \\
\text { in our product design process. }\end{array}$ & $\begin{array}{l}\text { (Kim, 2009; Koufteros, Cheng \& Lai, 2007; Swink \& } \\
\text { Nair, 2007; Vachon \& Klassen, 2007; Hsu et al., } \\
\text { 2008; Kulp et al., 2004; Flynn et al., 2010) }\end{array}$ \\
\hline & It12 & $\begin{array}{l}\text { We strive to establish long-term } \\
\text { relationships with suppliers. }\end{array}$ & $\begin{array}{l}\text { (Stank et al., 2001; Sanders, 2005; Flynn et al., } \\
\text { 2010; Bagchi et al., 2005; Briscoe \& Dainty, 2005) }\end{array}$ \\
\hline \multirow[t]{4}{*}{$\begin{array}{l}\text { Internal } \\
\text { integration }\end{array}$} & It13 & $\begin{array}{l}\text { We encourage employees to work } \\
\text { together to achieve common goals, } \\
\text { rather than encourage competition } \\
\text { among individuals. }\end{array}$ & $\begin{array}{l}\text { (Stank et al., 2001; Wong \& Boon-Itt, 2008; } \\
\text { Germain \& Iyer, 2006; Flynn et al., 2010; Giménez } \\
\text { \& Ventura, 2003) }\end{array}$ \\
\hline & It14 & $\begin{array}{l}\text { Departments in the plant } \\
\text { communicate frequently with each } \\
\text { other. }\end{array}$ & $\begin{array}{l}\text { (Kim, 2009; Sanders \& Premus, 2005; Stank et al., } \\
\text { 2001; Vickery et al., 2003; Wong \& Boon-Itt, 2008; } \\
\text { Germain \& Iyer, 2006; Flynn et al., 2010; Giménez } \\
\text { \& Ventura, 2003) }\end{array}$ \\
\hline & It15 & $\begin{array}{l}\text { Management works together well on } \\
\text { all important decisions }\end{array}$ & $\begin{array}{l}\text { (Narasimhan \& Kim, 2002; Sanders \& Premus, } \\
\text { 2005; Germain \& Iyer, 2006; Giménez \& Ventura, } \\
\text { 2003) }\end{array}$ \\
\hline & It16 & $\begin{array}{l}\text { Generally, speaking, everyone in the } \\
\text { plant works well together. }\end{array}$ & $\begin{array}{l}\text { (Sanders \& Premus, 2005; Wong \& Boon-Itt, 2008; } \\
\text { Giménez \& Ventura, 2003) }\end{array}$ \\
\hline
\end{tabular}

Table 1. Items selected in the survey 
We will start by analyzing the descriptive statistics, paying close attention to missing values, skip patterns, range of response values, asymmetry and kurtosis (Viladrich Segués \& Doval Dieguez, 2011; Doval Dieguez \& Viladrich Segués, 2011).

We will then carry out internal consistency testing to purify the items (inter-item correlations, Cronbach's alpha, squared multiple correlation, corrected item-total correlation). The set of items that pass the internal consistency testing will be analysed using exploratory factor analysis with maximum likelihood and varimax rotation, to verify if each of the items has high loads on the predicted scales, and with a multi-trait/multi-item analysis to see the discriminant validity (Doval Dieguez \& Viladrich Segués, 2011). And finally, a confirmatory factor analysis will be carried out using robust estimators, which will allow us to check the convergent and discriminant validity of the scales. This model incorporates the correlations of all the scales amongst themselves, given that certain theoretical evidence would appear to show that there is a certain overlapping between the constructs and that their correlations should therefore be taken into consideration (Flynn et al., 2010).

Convergent validity will be tested using four criteria. The first is that statistics of the robust model's goodness of fit are appropriate (P-value Robust Chi2 > 0.05; normed Chi2 < 5; CFI > 0.90; IFI > 0.90; MFI > 0.90; GFI > 0.85; RMSEA < 0.08) (Hair et al., 1999; Sila, 2007; Spreitzer, 1995; Tari, Molina \& Castejón, 2007; Ullman \& Bentler, 2004). Secondly, composite reliability will be checked as being over 0.7 (Hair et al., 1999). Thirdly, it will be checked that the Cronbach's alpha are over 0.70 (Hair et al., 1999; Lin, 2006). The fourth criterion will test whether variance extracted is over $40 \%$ (Hair et al., 1999). Discriminant validity will be checked using the test of variance extracted compared to squared correlations (Fornell \& Larcker, 1981; Hair et al., 1999; Farrell, 2010) and the confidence interval for correlations (Anderson \& Gerbing, 1988; Bagozzi, 1994). The analyses will be done with the SPSS and EQS programme using the maximum likelihood parameter estimation method (Ullman \& Bentler, 2004).

\section{Results}

Our sample comprises 266 plants. Of those, 66 companies in Sweden and Germany (24.8\%) did not respond to the question on the type of company, $26(9.8 \%)$ did not answer the question on the size of the company (the majority of these in South Korea and the US) and $29(10.9 \%)$ did not respond to the question on the level of vertical integration (once again South Korea and the US are the sub-sample with the highest number of missing values). The sampling distribution across countries is uniform and there are only major differences to a lesser degree amongst World-class companies in Australia and Finland; a greater proportion of transport companies in Germany; larger companies in Japan and South Korea and a greater degree of vertical integration in Germany, and a lesser degree in Sweden (Table 2). 


\begin{tabular}{|c|c|c|c|c|c|c|c|c|c|c|c|}
\hline \multirow[b]{2}{*}{ Count. } & \multirow[b]{2}{*}{ Tot } & \multicolumn{3}{|c|}{ Industry } & \multicolumn{3}{|c|}{ Plant size } & \multicolumn{4}{|c|}{ Vertical integration } \\
\hline & & Electr. & Machi. & Trans. & $50-250$ & $251-500$ & $>500$ & Not & Low & Med. & High \\
\hline Austria & 21 & 10 & 7 & 4 & 10 & 3 & 5 & 0 & 2 & 12 & 5 \\
\hline Finland & 30 & 14 & 6 & 10 & 15 & 10 & 5 & 1 & 5 & 16 & 6 \\
\hline Germany & 41 & 9 & 13 & 19 & 12 & 13 & 16 & 0 & 8 & 14 & 17 \\
\hline Italy & 27 & 10 & 10 & 7 & 14 & 6 & 7 & 2 & 4 & 14 & 6 \\
\hline Japan & 35 & 10 & 12 & 13 & 5 & 6 & 23 & 0 & 9 & 13 & 11 \\
\hline $\begin{array}{l}\text { South } \\
\text { Korea }\end{array}$ & 31 & 10 & 10 & 11 & 2 & 3 & 14 & 1 & 1 & 16 & 4 \\
\hline Spain & 28 & 9 & 9 & 10 & 12 & 8 & 7 & 0 & 7 & 9 & 9 \\
\hline Sweden & 24 & 7 & 10 & 7 & 10 & 8 & 5 & 2 & 7 & 13 & 0 \\
\hline USA & 29 & 9 & 11 & 9 & 6 & 8 & 7 & 1 & 8 & 8 & 6 \\
\hline Total & 266 & 88 & 88 & 90 & 86 & 65 & 89 & 7 & 51 & 115 & 64 \\
\hline
\end{tabular}

Table 2. Composition of the sample of companies

Practically all the sample plants answered the 16 items concerning the degree of integration. There were only missing values in 6 items (it05, it07, it13, it14, it15, it16). And these missing values stem, for the most part, from two plants so there is no point carrying out a detailed analysis of the missing values. For the majority of the items, the distribution of responses has a high average, a typically not very high deviation, negative asymmetry and are leptokurtic. In other words, the majority of responses are in the upper part of the scale (of around 5 and 6 on a seven-level scale). More than half of the items have a "grounding" effect and the minimum values do not tend to cover the whole scale, with a range of responses covering between 3 and 5 different levels of response (See Table 3).

\begin{tabular}{|l|l|r|r|r|r|r|r|r|}
\hline Item & \multicolumn{1}{|l}{ N } & Range & Minimum & Maximum & \multicolumn{1}{c|}{ Average } & \multicolumn{1}{c|}{ Typ. Dev. } & \multicolumn{1}{c|}{ Asymmetry } & \multicolumn{1}{c|}{ Kurtosis } \\
\hline It01 & 266 & 5.33 & 1.67 & 7.00 & 5.3429 & 0.77076 & -0.738 & 1.747 \\
\hline It02 & 266 & 4.00 & 3.00 & 7.00 & 5.6873 & 0.70058 & -0.328 & 0.037 \\
\hline It03 & 266 & 3.00 & 4.00 & 7.00 & 6.0724 & 0.51030 & -0.734 & 0.957 \\
\hline It04 & 266 & 4.67 & 2.00 & 6.67 & 4.6142 & 0.84354 & -0.142 & -0.288 \\
\hline It05 & 265 & 4.00 & 3.00 & 7.00 & 5.5844 & 0.70905 & -0.701 & 0.680 \\
\hline It06 & 266 & 4.00 & 3.00 & 7.00 & 5.6444 & 0.68590 & -0.911 & 1.352 \\
\hline It07 & 265 & 3.17 & 3.83 & 7.00 & 6.0305 & 0.60557 & -0.781 & 0.835 \\
\hline It08 & 266 & 2.89 & 4.11 & 7.00 & 5.7789 & 0.56771 & -0.315 & -0.084 \\
\hline It09 & 266 & 3.81 & 2.93 & 6.73 & 5.2711 & 0.66239 & -0.634 & 0.248 \\
\hline It10 & 266 & 3.60 & 3.40 & 7.00 & 5.5506 & 0.56121 & -0.564 & 1.027 \\
\hline It11 & 266 & 4.46 & 1.88 & 6.33 & 4.5870 & 0.80275 & -0.408 & 0.038 \\
\hline It12 & 266 & 3.50 & 3.50 & 7.00 & 5.7113 & 0.60831 & -0.497 & 0.319 \\
\hline It13 & 265 & 3.11 & 3.89 & 7.00 & 5.8400 & 0.56874 & -0.690 & 1.022 \\
\hline It14 & 265 & 4.00 & 3.00 & 7.00 & 5.3782 & 0.72600 & -0.452 & 0.332 \\
\hline It15 & 265 & 5.33 & 1.67 & 7.00 & 5.1967 & 0.77881 & -0.852 & 1.413 \\
\hline It16 & 265 & 4.00 & 3.00 & 7.00 & 5.4385 & 0.76041 & -0.626 & 0.431 \\
\hline
\end{tabular}

Table 3. Descriptive statistics 
Following internal consistency testing (Tables 4 and 5), Item 13 was removed from the internal integration scale given that its correlation with other items on the scale was too low. So is its correlation with the scale as a whole as well as its multiple squared correlation. Similarly, there would be a slight improvement to Chronbach's alpha were it to be eliminated. This would indicate that the item be eliminated. The external integration scale for It05 is not related to the other items and this penalizes the statistics. The item should probably be eliminated if it does not pass the next stages of analysis. Were it be eliminated, the average correlations between items would slightly improve ( 0.462 with a minimum of 0.447 and a maximum of 0.472 ), and the Cronbach's Alpha would remain at 0.72 . On the other scales, the items with the poorest results are It04 and It11, which have the squared multiple correlation and would result in a slight increase to Cronbach's Alpha were they to be eliminated. This is the same case for It05, whereby it remains until subsequent analysis determined if it should be eliminated or not.

\begin{tabular}{|c|c|c|c|c|c|c|c|}
\hline & Average & Minimum & Maximum & Alpha & Lim Inf IC Alfa & Lim Inf IC Alfa & No. elements \\
\hline $\begin{array}{l}\text { Customer } \\
\text { integration }\end{array}$ & 0.480 & 0.283 & 0.574 & 0.775 & 0.727 & 0.816 & 4 \\
\hline $\begin{array}{l}\text { External } \\
\text { Integration }\end{array}$ & 0.394 & 0.299 & 0.472 & 0.716 & 0.656 & 0.768 & 4 \\
\hline $\begin{array}{l}\text { Supplier } \\
\text { integration }\end{array}$ & 0.448 & 0.285 & 0.568 & 0.753 & 0.700 & 0.798 & 4 \\
\hline $\begin{array}{l}\text { Internal } \\
\text { integration }\end{array}$ & 0.550 & 0.516 & 0.582 & 0.785 & 0.765 & 0.826 & 3 \\
\hline
\end{tabular}

Table 4. Inter-item correlations and Cronbach's alpha

Following this, a multi-trait/multi-item analysis was carried out (Table 5). To pass the test, the difference between the corrected item-total correlation and the item correlation with other scales should be greater than $0.123-2 *$ standard error (Doval Dieguez \& Viladrich Segués, 2011)-. Item05, earmarked following earlier analysis as potentially having problems, has more correlation to an access other than that of the one theoretically assigned to it and its correlation is not sufficiently different in the other two axes. It is therefore an item that could create issues during discriminant validation and will therefore be eliminated from the model. Currently, items it04 and It11 have passed the test.

The results of the exploratory factor analysis with factor extraction techniques using the maximum likelihood method and Varimax criterion under orthogonal rotation (Table 6), indicate that the sampling adaptation index (0.821) and Bartlett's test of sphericity $(p<0.000)$ are adequate. There are 4 factors with values greater than 1 , and which make up for $63.8 \%$ of the variance. The items are grouped around the factors proposed by the theory. Factor loadings are all greater than 0.5 in the envisaged factor and have a different of more than 0.3 with regard to the loads in other factors. For this reason, no modifications are made to the scales following analysis. 


\begin{tabular}{|c|c|c|c|c|c|c|}
\hline item & $\begin{array}{l}\text { Squared } \\
\text { multiple } \\
\text { correlation }\end{array}$ & $\begin{array}{l}\text { Cronbach's Alpha if } \\
\text { the element is } \\
\text { eliminated }\end{array}$ & $\begin{array}{l}\text { Customer } \\
\text { integration }\end{array}$ & $\begin{array}{c}\text { External } \\
\text { Integration }\end{array}$ & $\begin{array}{c}\text { Supplier } \\
\text { integration }\end{array}$ & $\begin{array}{c}\text { Internal } \\
\text { integration }\end{array}$ \\
\hline It01 & 0.435 & 0.676 & 0.656 & $0.310^{* *}$ & $0.284^{* *}$ & $0.334^{* *}$ \\
\hline It02 & 0.472 & 0.673 & 0.668 & $0.330^{* *}$ & $0.389^{* *}$ & $0.337^{* *}$ \\
\hline It03 & 0.370 & 0.752 & 0.539 & $0.309^{* *}$ & $0.288^{* *}$ & $0.390^{* *}$ \\
\hline It04 & 0.293 & 0.770 & 0.510 & $0.215^{* *}$ & $0.248^{* *}$ & $0.241^{* *}$ \\
\hline It05 & 0.169 & 0.717 & $0.494^{* *}$ & 0.409 & $0.308^{* *}$ & $0.297^{* *}$ \\
\hline It06 & 0.331 & 0.614 & $0.128^{*}$ & 0.564 & $0.381^{* *}$ & $0.243^{* *}$ \\
\hline It07 & 0.298 & 0.642 & $0.232^{* *}$ & 0.525 & $0.249^{* *}$ & $0.262^{* *}$ \\
\hline It08 & 0.301 & 0.639 & $0.201^{* *}$ & 0.537 & $0.315^{* *}$ & $0.254^{* *}$ \\
\hline It09 & 0.406 & 0.652 & $0.336^{* *}$ & $0.294^{* *}$ & 0.624 & $0.209^{* *}$ \\
\hline It10 & 0.435 & 0.667 & $0.290^{* *}$ & $0.402^{* *}$ & 0.620 & $0.253^{* *}$ \\
\hline It11 & 0.310 & 0.736 & $0.253^{* *}$ & $0.318^{* *}$ & 0.507 & $0.199^{* *}$ \\
\hline It12 & 0.335 & 0.726 & $0.300^{* *}$ & $0.304^{* *}$ & 0.489 & $0.229^{* *}$ \\
\hline It14 & 0.424 & 0.680 & $0.328^{* *}$ & $0.274^{* *}$ & $0.172^{* *}$ & 0.651 \\
\hline It15 & 0.361 & 0.735 & $0.346^{* *}$ & $0.315^{* *}$ & $0.256^{* *}$ & 0.599 \\
\hline It16 & 0.394 & 0.710 & $0.332^{* *}$ & $0.312^{* *}$ & $0.289^{* *}$ & 0.622 \\
\hline
\end{tabular}

Table 5. In bold, the corrected item-total correlation (as this is the prescribed scale for the item), the rest of the correlations are routine Pearson correlations

\begin{tabular}{|c|c|r|r|r|}
\hline Item & Factor1 & Factor2 & Factor3 & Factor4 \\
\hline It01 & $\mathbf{0 . 7 2 5}$ & 0.121 & 0.160 & 0.106 \\
\hline It02 & $\mathbf{0 . 7 3 8}$ & 0.256 & 0.146 & 0.092 \\
\hline It03 & $\mathbf{0 . 5 9 4}$ & 0.149 & 0.247 & 0.129 \\
\hline It04 & $\mathbf{0 . 5 6 0}$ & 0.124 & 0.112 & -0.001 \\
\hline It06 & -0.029 & 0.299 & 0.122 & $\mathbf{0 . 6 5 9}$ \\
\hline It07 & 0.151 & 0.066 & 0.131 & $\mathbf{0 . 6 7 0}$ \\
\hline It08 & 0.094 & 0.213 & 0.124 & $\mathbf{0 . 5 8 8}$ \\
\hline It09 & 0.198 & $\mathbf{0 . 7 2 5}$ & 0.060 & 0.074 \\
\hline It10 & 0.147 & $\mathbf{0 . 6 7 4}$ & 0.109 & 0.255 \\
\hline It11 & 0.106 & $\mathbf{0 . 5 8 5}$ & 0.085 & 0.140 \\
\hline It12 & 0.183 & $\mathbf{0 . 5 2 6}$ & 0.107 & 0.163 \\
\hline It14 & 0.192 & 0.025 & $\mathbf{0 . 7 6 8}$ & 0.100 \\
\hline It15 & 0.168 & 0.188 & $\mathbf{0 . 6 8 6}$ & 0.130 \\
\hline It16 & 0.218 & 0.119 & $\mathbf{0 . 6 3 8}$ & 0.181 \\
\hline
\end{tabular}

Table 6. Rotated factor matrix Extraction method: Maximum likelihood

The final step in the process was the carrying out confirmatory factor analysis to complete checking the convergent and discriminant validation of each scale. We start with the joint measurement model, which is the best representation of the theoretical model where the scales are interlinked (Flynn et al., 2010). In the first version, two scales had 4 items, and the others 3 items. All the factorial loads were greater than 0.6 with the exception of two items (It04 and It11), which have been eliminated from the definitive version. In the definitive 
version, all scales have three items, which is why we choose to present the goodness of fit statistics of the model as a whole in stead of doing so scale by scale, as they can not be independently measured when the number of items in the scale is less than 4. The model adjustment statistics are exceptionally good (normed Chi2 robust $=1.32$; $\mathrm{p}$-value chi2 satorra $=.064 ; \mathrm{CFI}=.98 ; \quad \mathrm{IFI}=.98 ; \mathrm{MFI}=.97 ; \mathrm{RMSA}=.04 ; \quad \mathrm{GFI}=.96 ; \quad \mathrm{AGFI}=.93)$. All estimations are significant and the standardised factorial loads are all greater than 0.6 (Figure 1). The extracted variance of the scales is between .45 and .56 and the compound reliability Cronbach's alpha are in all cases greater than the cut-off value of .70 (Table 7). These analyses confirm the convergent validity of the proposed scales. At the same time, the scales also pass the test of variance extracted compared to squared correlations and the confidence interval for correlations (Table 7).

\begin{tabular}{|l|r|r|r|r|r|r|r|r|}
\hline & \multicolumn{1}{|c|}{$\begin{array}{c}\text { Num } \\
\text { Items }\end{array}$} & \multicolumn{1}{|c|}{ Alpha } & \multicolumn{1}{c|}{ EVA } & $\begin{array}{c}\text { Comp. } \\
\text { Rel. }\end{array}$ & \multicolumn{1}{c|}{ Cust. Int. } & Ext. inte. & \multicolumn{1}{c|}{ Supp. Int. } & $\begin{array}{c}\text { Intern. } \\
\text { Int. }\end{array}$ \\
\hline $\begin{array}{l}\text { Customer } \\
\text { integration }\end{array}$ & 3 & 0.77 & 0.55 & 0.79 & $\mathbf{0 . 7 4}$ & 0.35 & 0.56 \\
\hline $\begin{array}{l}\text { External } \\
\text { Integration }\end{array}$ & 3 & 0.71 & 0.45 & 0.71 & $(0.30,0.41)$ & $\mathbf{0 . 6 7}$ & 0.52 & 0.44 \\
\hline $\begin{array}{l}\text { Supplier } \\
\text { integration }\end{array}$ & 3 & 0.74 & 0.51 & 0.75 & $(0.47,0.56)$ & $(0.48,0.57)$ & $\mathbf{0 . 7 1}$ & 0.36 \\
\hline $\begin{array}{l}\text { Internal } \\
\text { integration }\end{array}$ & 3 & 0.79 & 0.56 & 0.79 & $(0.49,0.62)$ & $(0.39,0.49)$ & $(0.31,0.40)$ & $\mathbf{0 . 7 5}$ \\
\hline
\end{tabular}

Table 7. Results of confirmatory factor analysis. In the first four columns: Number of items of the scale, Cronbach's alpha, Extracted Variance and compound reliability of each of the scales. In the last four columns, in the upper diagonal are the correlations between scales; in the lower diagonal, the $95 \%$ confidence interval for the correlation between scales and, in bold on the diagonal, the square root of the extracted variance

Now that the convergent and discriminant validity of the scales has been shown, we are going to present the scale benchmarks by breaking down the percentiles into 10, 25, 50, 75 and $90 \%$ for each scale (Table 8 ). Firstly, we will see if the distribution of the sub-samples for each control variable of the supply chain integration scale are significant and if this is the case, we will present an independent benchmark for each of the sub-samples (Doval Dieguez \& Viladrich Segués, 2011).

There are no significant differences in the sub-samples based on its size or the level of vertical integration. The general benchmark can therefore be applied to these business sub-groups. There are only significant differences by industry for the degree of customer integration between machinery and the other three sectors. Although the differences are significant for the sub-samples of each country, the number of companies available in each sample is two small to be considered representative and therefore does not require the benchmark to be broken down. 


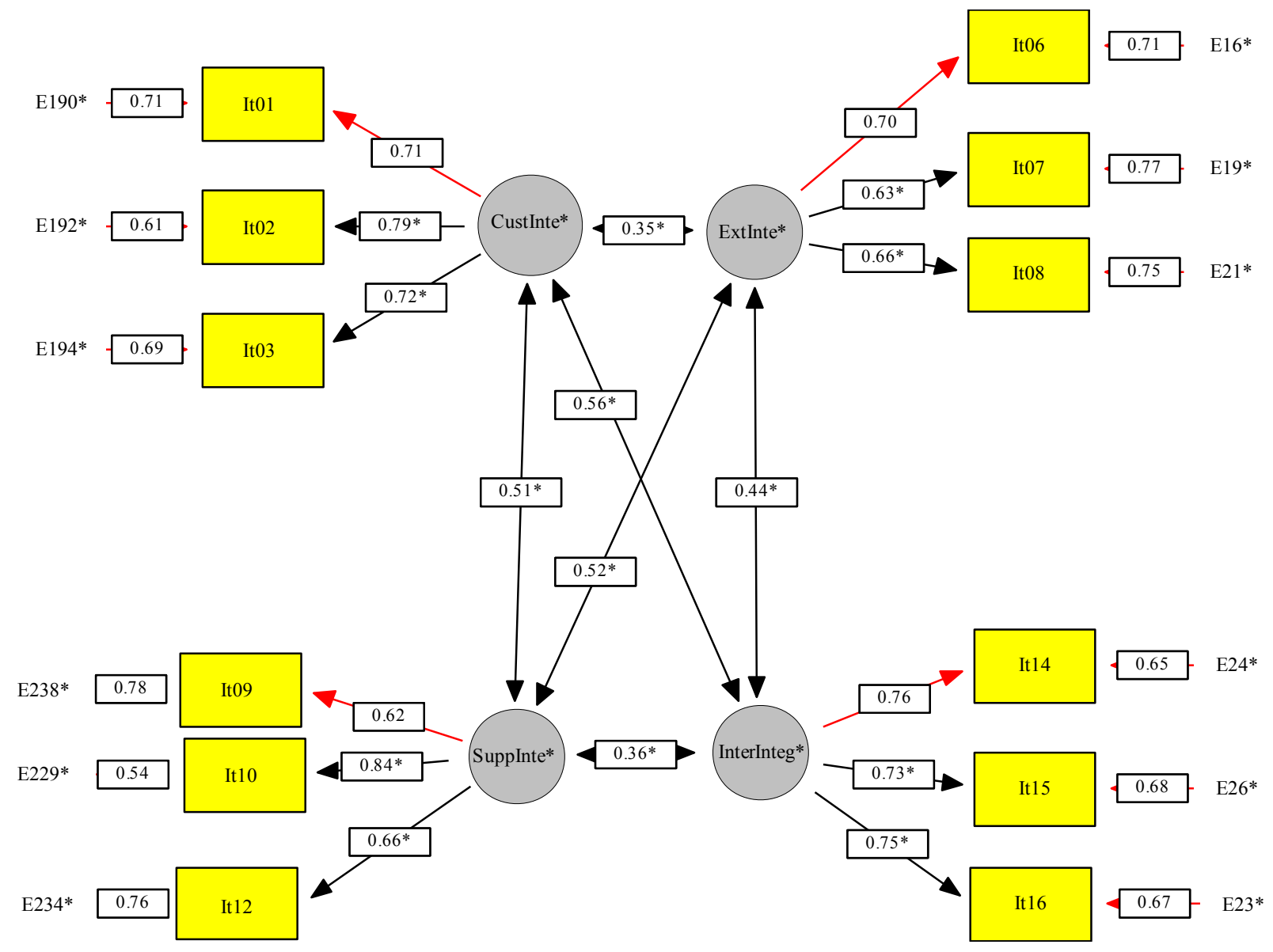

Figure 1. Standardized estimate joint measurement model

\begin{tabular}{|c|c|c|c|c|c|c|c|}
\hline & & $\begin{array}{l}\text { CustIntegr } \\
\text { Total }\end{array}$ & $\begin{array}{l}\text { CustIntegr } \\
\text { Machinery }\end{array}$ & $\begin{array}{l}\text { CustIntegr } \\
\text { Electr. or } \\
\text { transp. }\end{array}$ & $\begin{array}{l}\text { ExtIntegr } \\
\text { Total }\end{array}$ & $\begin{array}{c}\text { SuppIntegr } \\
\text { Total }\end{array}$ & $\begin{array}{c}\text { InterIntegr } \\
\text { Total }\end{array}$ \\
\hline \multirow{2}{*}{$N$} & Valid & 266 & 88 & 178 & 265 & 266 & 265 \\
\hline & Missing & 0 & 0 & 0 & 1 & 0 & 1 \\
\hline \multirow{5}{*}{ Percentiles } & 10 & 15.1 & 14.4 & 15.3 & 15.4 & 14.6 & 13.5 \\
\hline & 25 & 16.0 & 15.4 & 16.3 & 16.4 & 15.6 & 14.8 \\
\hline & 50 & 17.1 & 16.6 & 17.3 & 17.5 & 16.6 & 16.0 \\
\hline & 75 & 18.3 & 17.7 & 18.4 & 18.4 & 17.6 & 17.5 \\
\hline & 90 & 19.0 & 18.7 & 19.3 & 19.3 & 18.3 & 18.1 \\
\hline
\end{tabular}

Table 8. Scoring benchmark for the supply chain integration scales

\section{Conclusions}

This research paper provides an overview of the latest chain supply integration scales and expresses the need to formulate measurement instruments that allow one to identify the degree of use of each of the four constructs in companies (internal integration, external integration, integration with clients and integration with suppliers).

Starting out with a set of items, created especially for this research, 4 scales are proposed, and are subsequently validated using a broad sample. The definitive scales show excellent psychometric properties, although they do point to certain limitations such as, for example, the 
generalization of other industrial sectors (given that the sample consists of companies from only three sectors); or that the range of responses are concentrated in the upper part of the scale. This behaviour could stem from the characteristics of the sectors chosen for the sample, in which case it would be desirable to test out these scales in the future using a broader sampling and with plants from different sectors. In this way, the benchmark could be extended to be able to analyse differences by country or by sector (if these were available). Developing similar scales focusing on service companies that have their own set of characteristics when it comes to understanding and applying supply chain integration would be required.

The outcomes of this paper have obvious academic implications as it responds to requests expressed in recently published articles in this field, which asked for a clearer and more concise designation of the supply chain integration measurement scales. In this way, more reliable and accurate data could be taken to analyse the relations between these constructs with other variables of interest to the academic and professional fields, such as for example the outcomes or production efficiency.

From a professional perspective, this paper contributes to providing scales that are valid as a diagnostic tool for best practices, as well as providing a benchmark with which to compare the score for each individual plant against a collection of industrial companies from the machinery, electronics and transportation sectors.

\section{Acknowledgments}

This paper has been made possible thanks to grant DPI2006-05531 (HPM Project-Spain: Project for high performance manufacturing) awarded by the Spanish Ministry of Education and Science and the project "CORSARI MAGIC DPI2010-18243" by the Spanish Ministry of Science and Innovation within the Program "Proyectos de Investigación Fundamental No Orientada".

\section{References}

Alfalla-Luque, R. \& Medina-López, C. (2009). Supply Chain Management: Unheard of in the 1970s, core to today's company. Business History, 51(2), 202-221. http://dx.doi.org/10.1080/00076790902726558

Alfalla-Luque, R., Medina-Lopez, C. \& Dey, P.K. (2012). Supply chain integration framework using literature review. Production, Planning and Control. http://dx.doi.org/10.1080/09537287.2012.666870

Alfalla-Luque, R., Medina-Lopez, C. \& Schrage, H. (2012). A study of supply chain integration in the aeronautics sector. Production and Control. http://dx.doi.org/10.1080/09537287.2012.666868

Anderson, J.C. \& Gerbing, D.W. (1988). Structural Equation Modeling in Practice: A Review and Recommended Two-Step Approach. Psychological Bulletin, 103(3), 411-423. 
Bagchi, P.K., Ha, B.C., Skjoett-Larsen, T., \& Soerensen, L.B. (2005). Supply chain integration: a European survey. The International Journal of Logistic Management, 16(2), 275-294. http://dx.doi.org/10.1108/09574090510634557

Bagozzi, R.P. (1994). Structural Equation Models in marketing research: Basic principles. In R.P.Bagozzi (Ed.), Principles of Marketing Research, pp. 317-385. Malden, MA: Blackwell Publishers.

Baxter, R. (2009). Reflective and formative metrics of relationship value: A commentary essay. Journal of Business Research, 62(12), 1370-1377. http://dx.doi.org/10.1016/j.jbusres.2008.12.004

Bayraktar, E., Jothishankar, M.C., Tatoglu, E., \& Wu, T. (2007). Evolution of operations management- past, present and future. Management Research News, 30(11), 843-871. http://dx.doi.org/10.1108/01409170710832278

Bessant, J., Kaplinsky, R., \& Morris, M. (2003). Developing capability through learning networks. International Journal of Technology Management \& Sustainable Development, 2(1), 19-38. http://dx.doi.org/10.1386/ijtm.2.1.19/0

Briscoe, G. \& Dainty, A. (2005). Construction supply chain integration: An elusive goal? Supply Chain Management: An International Journal, 10(4), 319-326. http://dx.doi.org/10.1108/13598540510612794

Brown, T.A. (2006). Confirmatory factor analysis for applied research. Guilford Press.

Bruce, M., Daly, L., \& Towers, N. (2004). Lean or agile - A solution for supply chain management in the textiles and clothing industry? International Journal of Operations \& Production Management, 24(1-2), 151-170. http://dx.doi.org/10.1108/01443570410514867

Byrne, B. (2006). Structural equation modelling with EQS: Basic concepts, applications and programming. London: Lawrence Erlbaum.

Cagliano, R., Caniato, F., \& Spina, G. (2006). The linkage between supply chain integration and manufacturing improvement programmes. International Journal of Operations and Production Management, 26(3), 282-299. http://dx.doi.org/10.1108/01443570610646201

Carter, C.R., Sanders, N.R., \& Dong, Y. (2008). Paradigms, revolutions, and tipping points: The need for using multiple methodologies within the field of supply chain management. Journal of Operations Management, 26(6), 693-696. http://dx.doi.org/10.1016/j.jom.2008.07.002

Chang, W.L., Ik-Whan, G.K., \& Dennis, S. (2007). Relationship between supply chain performance and degree of linkage among supplier, internal integration, and customer. Supply Chain Management: An International Journal, 12(6), 444-452. http://dx.doi.org/10.1108/13598540710826371 
Danese, P., Formentini, M., Romano, P., \& Bortolotti, T. (2010). An empirical study on the joint effect of Supply Chain Integration and International Sourcing on Delivery Performance. Paper presented at the Proceedings Euroma Conference 2010 Oporto, Portugal.

Doval Dieguez, E. \& Viladrich Segués, M.C. (2011). Desarrollo y adaptación de cuestionarios en el ámbito de la salud. Bellaterra: Laboratori d'Estadística Aplicada i de Modelització (UAB).

Escrig Tena, A.B. \& Bou-Llusar, J.C. (2005). A model for evaluating organizational competencies: An application in the context of a quality management initiative. Decision Sciences, 36(2), 221-257. http://dx.doi.org/10.1111/j.1540-5414.2005.00072.x

Farrell, A.M. (2010). Insufficient discriminant validity: A comment on Bove, Pervan, Beatty and Shiu (2009). Journal of Bussiness Research, 63(3), 324-327. http://dx.doi.org/10.1016/j.jbusres.2009.05.003

Flynn, B.B., Huo, B., \& Zhao, X. (2010). The impact of supply chain integration on performance: A contingency and configuration approach. Journal of Operations Management, 28, 58-71. http://dx.doi.org/10.1016/j.jom.2009.06.001

Flynn, B.B., Wu, S.J., \& Melnyk, S.A. (2010). Operational capabilities: Hidden in plain view. Business Horizons, 53, 247-256. http://dx.doi.org/10.1016/j.bushor.2010.01.001

Fornell, C. \& Larcker, D.F. (1981). Evaluating Structural Equation Models with Unobservable Variables and Measurement Error. Journal of marketing research, 28, 39-50. http://dx.doi.org/10.2307/3151312

Germain, R. \& Iyer, K. (2006). The Interaction of Internal and Downstream Integration and its Association with Performance. Journal of Business Logistics, 27(2), 29-52. http://dx.doi.org/10.1002/j.2158-1592.2006.tb00216.x

Giménez, C. \& Ventura, E. (2003). Supply Chain Management as a competitive advantage in the Spanish grocery sector. International Journal of Logistics Management, 14(1), 77-88. http://dx.doi.org/10.1108/09574090310806558

Hair, J.F., Anderson, R.E., Tatham, R.L., \& Black, W.C. (1999). Análisis de datos multivariante. (40 ed.). Prentice Hall.

Harrison, A. \& Van Hoek, R. (2005). Logistics Management and Strategy. Pearson Education.

Hayes, R.H. \& Wheelwright, S.C. (1984). Restoring Our Competitive Edge: Competing Through Manufacturing. New York: John Wiley \& Sons.

Hofstede, G. (1998). Attitudes, values and organizational culture: Disentangling the concepts. Organization Studies, 19(3), 477-492. http://dx.doi.org/10.1177/017084069801900305 
Hsu, C., Kannan, V.R., Tan, K., \& Leong, G.K. (2008). Information sharing, buyer-supplier relationships, and firm performance: A multi-region analysis. International Journal of Physical Distribution and Logistics Management, 38(4), 296-310. http://dx.doi.org/10.1108/09600030810875391

Kannan, V.R. \& Tan, K.C. (2005). Just in time, total quality management, and supply chain management: understanding their linkages and impact on business performance. OmegaInternational Journal of Management Science, 33(2), 153-162. http://dx.doi.org/10.1016/j.omega.2004.03.012

Kaynak, H. \& Hartley, J.L. (2008). A replication and extension of quality management into the supply chain. Journal of Operations Management, 26(4), 468-489. http://dx.doi.org/10.1016/j.jom.2007.06.002

Kim, S.W. (2009). An investigation on the direct and indirect effect of supply chain integration on firm performance. International Journal of Production Economics, 119(2), 328-346. http://dx.doi.org/10.1016/j.ijpe.2009.03.007

Koufteros, X.A., Cheng, T.C.E., \& Lai, K.H. (2007). "Black-box" and "gray-box" supplier integration in product development: Antecedents, consequences and the moderating role of firm size. Journal of Operations Management, 25, 847-870. http://dx.doi.org/10.1016/j.jom.2006.10.009

Kulp, S.C., Lee, H.L., \& Ofek, E. (2004). Manufacturer benefits from information integration with retail customers. Management Science, 50(4), 461-444. http://dx.doi.org/10.1287/mnsc. 1030.0182

Li, S.H., Rao, S.S., Ragu-Nathan, T.S., \& Ragu-Nathan, B. (2005). Development and validation of a measurement instrument for studying supply chain management practices. Journal of Operations Management, 23(6), 618-641. http://dx.doi.org/10.1016/j.jom.2005.01.002

Li, S., Ragu-Nathan, B., Ragu-Nathan, T.S., \& Subba Rao, S. (2006). The impact of supply chain management practices on competitive advantage and organizational performance. Omega, 34(2), 107-124. http://dx.doi.org/10.1016/j.omega.2004.08.002

Lin, W.B. (2006). The exploration of employee involvement model. Expert Systems with Applications, 31(1), 69-82. http://dx.doi.org/10.1016/j.eswa.2005.09.035

MacDuffie, J.P. \& Helper, S. (1997). Creating Lean Suppliers - Diffusing Lean Production Throughout the Supply Chain. California Management Review, 39(4), 118-151. http://dx.doi.org/10.2307/41165913

Martinez Jurado, P.J. \& Moyano Fuentes, J. (2011). Lean Production y gestión de la cadena de suministro en la industria aeronáutica. Investigaciones Europeas de Dirección y Economía de la Empresa, 17(1), 137-157. http://dx.doi.org/10.1016/S1135-2523(12)60048-3 
Narasimhan, R. \& Kim, S.W. (2002). Effect of supply chain integration on the relationship between diversification and performance: evidence from Japanese and Korean firms. Journal of Operations Management, 20, 303-323. http://dx.doi.org/10.1016/S0272-6963(02)00008-6

Oliver, N. \& Delbridge, R. (2002). The characteristics of high performing supply chains. International Journal of Technology Management, 23(1-3), 60-73. http://dx.doi.org/10.1504/IJTM.2002.002998

Pagell, M., Katz, J. P., \& Sheu, C. (2005). The importance of national culture in operations management research. International Journal of Operations and Production Management, 25(4), 71-394. http://dx.doi.org/10.1108/01443570510585552

Pagell, M. \& LePine, J.A. (2002). Multiple case studies of team effectiveness in manufacturing organizations. Journal of Operations Management, 20(5), 619-639. http://dx.doi.org/10.1016/S0272-6963(02)00030-X

Roth, A.V., Schroeder, R.G., Huang, X., \& Kristal, M.M. (2008). Handbook of metrics for research in Operations Management multi-item measurement scales and objective items. New york: SAGE publications.

Sanders, N.R. (2005). IT Alignment in Supply Chain Relationships: A Study of Supplier Benefits. The Journal of Supply Chain Management, Spring 4-13. http://dx.doi.org/10.1111/j.1055-6001.2005.04102001.x

Sanders, N.R. \& Premus, R. (2005). Modeling the relationship between firm IT capability, collaboration, and performance. Journal of Business Logistics, 26(1), 1-23. http://dx.doi.org/10.1002/j.2158-1592.2005.tb00192.x

Sezen, B. (2008). Relative effects of design, integration and information sharing on supply chain performance. Supply Chain Management: An International Journal, 13(3), 233-240. http://dx.doi.org/10.1108/13598540810871271

Sila, I. (2007). Examining the effects of contextual factors on TQM and performance through the lens of organizational theories: An empirical study. Journal of Operations Management, 25(1), 83-109. http://dx.doi.org/10.1016/j.jom.2006.02.003

Spreitzer, G.M. (1995). Psychological Empowerment in the Workplace - Dimensions, Measurement, and Validation. Academy of management Journal, 38(5), 1442-1465. http://dx.doi.org/10.2307/256865

Stank, T.P., Keller, S. B., \& Daugherty, P.J. (2001). Supply chain collaboration and logistical service performance. Journal of Business Logistics, 22(1), 29-48. http://dx.doi.org/10.1002/j.2158-1592.2001.tb00158.x 
Swink, M. \& Nair, A. (2007). Capturing the competitive advantages of AMT: Designmanufacturing integration as a complementary asset. Journal of Operations Management, 25(3), 736-754. http://dx.doi.org/10.1016/j.jom.2006.07.001

Tan, K.C., Lyman, S.B., \& Wisner, J.D. (2002). Supply chain management: a strategic perspective. International Journal of Operations \& Production Management, 22(5), 614-631. http://dx.doi.org/10.1108/01443570210427659

Tari, J.J., Molina, J.F., \& Castejón, J.L. (2007). The relationship between quality management practices and their effects on quality outcomes. European Journal of Operational Research, 183(2), 483-501. http://dx.doi.org/10.1016/j.ejor.2006.10.016

Thun, J.H. (2010). Angles of integration: an empirical analysis of the alignment of internetbased information technology and global supply chain integration. Journal of Supply Chain Management, 46(2), 30-44. http://dx.doi.org/10.1111/j.1745-493X.2010.03188.x

Topolsek, D. (2011). The impact of collaboration or collaborative behaviour on the level of internal integration: Case study of Slovenian retailers and motor vehicle repair companies. African Journal of Business Management, 5(26), 10345-10354.

Ullman, J.B. \& Bentler, P.M. (2004). Structural Equation Modeling. In M.Hardy \& A. Bryman (Eds.), Handbook of Data Analysis, pp. 431-458. SAGE. http://dx.doi.org/10.4135/9781848608184.n19

Underhill, G. (2001). Productivity in Small and Medium Enterprises. Management Services, 45(4), 8-12.

Vachon, S. \& Klassen, R.D. (2007). Supply chain management and environmental technologies: The role of integration. International Journal of Production Research, 45(2), 401-423. http://dx.doi.org/10.1080/00207540600597781

Vickery, S.K., Jayaram, J., Droge, C., \& Calantone, R. (2003). The effects of an integrative supply chain strategy on customer service and financial performance: An analysis of direct versus indirect relationships. Journal of Operations Management, 21(5), 523-539. http://dx.doi.org/10.1016/j.jom.2003.02.002

Viladrich Segués, M.C. \& Doval Dieguez, E. (2011). Medición: fiabilidad y validez. Bellaterra: Laboratori d'Estadística Aplicada i de Modelització (UAB).

Wong, C.Y. \& Boon-Itt, S. (2008). The influence of institutional norms and environmental uncertainty on supply chain integration in the Thai automotive industry. International Journal of Production Economics, 115(2), 400-410. http://dx.doi.org/10.1016/j.ijpe.2008.05.012 
Zhao, X., Huo, B., Selen, W., \& Yeung, J.H.Y. (2011). The impact of internal integration and relationship commitment on external integration. Journal of Operations Management, 29(1-2), 17-32. http://dx.doi.org/10.1016/j.jom.2010.04.004

Zhu, Q., Sarkis, J., \& Lai, K.h. (2008). Confirmation of a measurement model for green supply chain management practices implementation. International Journal of Production Economics, 111(2), 261-273. http://dx.doi.org/10.1016/j.ijpe.2006.11.029

Journal of Industrial Engineering and Management, 2013 (www.jiem.org)

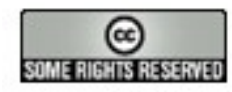

Article's contents are provided on a Attribution-Non Commercial 3.0 Creative commons license. Readers are allowed to copy, distribute and communicate article's contents, provided the author's and Journal of Industrial Engineering and Management's names are included. It must not be used for commercial purposes. To see the complete license contents, please visit http://creativecommons.org/licenses/by-nc/3.0/. 